\title{
Introduction - Emergency Operation Technologies for Sudden Water Pollution Accidents
}

\author{
Xiaohui Lei, Hezhen Zheng and Lingzhong Kong
}

\section{Long-distance water diversion projects}

Water is an important basic resource for human survival, social and economic development, and ecological environment stability [1]. With population growth, economic development, and climate change, many countries and regions face water shortage due to the uneven spatial-temporal distribution of water resources $[2,3]$. Shortage of water resources will affect food safety, economic development, and ecological environment health. This is one of the major difficulties that the world has to face in the future and a major obstacle to realize sustainable development $[4,5]$. It is an important way to solve the crisis of water resources in some areas by carrying out water diversion projects to transfer water from the areas where water is abundant to the places lacking of water [6].

\subsection{Main long-distance water diversion projects in the world}

It has been a long history of building water diversion projects by all the countries around the world. The earliest project can be traced back to $2400 \mathrm{BC}$ in the ancient Egypt, transferring the water of the Nile River to irrigate the southern Ethiopia plateau. With the development of social economy, the distance, range, transferable water amount, benefit, construction, and management levels of water diversion projects are gradually improved [7]. Until now, 350 long-distance water diversion projects have been built in at least 39 countries [8]. The following are some typical ones in the world.

\subsubsection{California north-to-south water diversion project (America)}

The main work of this Project Phase I was completed in 1973, successfully providing industrial and living water for 17 million people centering around Los Angeles. The main canal is $1138 \mathrm{~km}$ long in total, with a multi-year average water diversion amount of 5.2 billion $\mathrm{m}^{3}$ and a water diversion flow of $284 \mathrm{~m}^{3} / \mathrm{s}$.

\subsubsection{Central Arizona Project (America)}

This project started from 1968, from Lake Havasu in the west to Tucson in the southeast. The main canal is totally $539 \mathrm{~km}$ long with a multi-year average water diversion amount of 1.85 billion $\mathrm{m}^{3}$, and the water diversion amounts of three canals are 85,78 , and $62 \mathrm{~m}^{3} / \mathrm{s}$, respectively. 


\subsubsection{Quebec water transfer project (Canada)}

This project started in 1974 and was planned mainly for irrigation, with excess water for water power development. The main canal is $861 \mathrm{~km}$ long in total, with a multi-year average water diversion amount of 25.2 billion $\mathrm{m}^{3}$ and a water diversion flow of $1590 \mathrm{~m}^{3} / \mathrm{s}$.

\subsubsection{Volga to Moscow water diversion project (the former Soviet Union)}

This project started in 1932, transferring water from the Volga River to Moscow. The main canal is $224 \mathrm{~km}$ long in total, with a multi-year average water diversion amount of 2.1 billion $\mathrm{m}^{3}$ and a water diversion flow of $78 \mathrm{~m}^{3} / \mathrm{s}$.

\subsubsection{West to east water transfer project (Pakistan)}

This project started in 1960, transferring water from the Indus River to the east which is used mainly for irrigation and for power generation. The main canal is $622 \mathrm{~km}$ long in total, with a multi-year average water diversion amount of $14.8 \mathrm{bil}-$ lion $\mathrm{m}^{3}$ and a water diversion flow of $614 \mathrm{~m}^{3} / \mathrm{s}$.

\subsubsection{Snowy Mountains Scheme (Australia)}

This project started in 1949 and is mainly used for power generation with reregulated water for irrigation. The pipeline and tunnel are totally $224 \mathrm{~km}$ long, with a multi-year average water diversion amount of 1.13 billion $\mathrm{m}^{3}$.

\subsection{Main long-distance water diversion projects in China}

China's total water resources are about 2812.4 billion $\mathrm{m}^{3}$, ranking sixth in the world, but the per capita water resource quantity is only 1/4 of the world average. Moreover, the temporal and spatial distribution of water resources in China is very uneven, with more water in the south and less water in the north. This aggravates the shortage of water resources. In order to solve this problem, China began the construction of water diversion projects very early. From 486 to 219 BC, China successively carried out the Hanggou Project transferring the water in the Yangtze River into the Huaihe River, the Honggou Project transferring the water in the Yellow River into the Huaihe River, etc. Since 1949, China has completed construction of a series of water transfer projects, which play an important role in alleviating the uneven distribution and tense situation of water resources and promoting the development of local economy. There are approximately 20 main long-distance water diversion projects in China. The following are some typical ones:

\subsubsection{Water diversion project from the Yangtze River to the northern plains of Jiangsu Province}

This project has the water in the Yangtze River pumped at Jiangdu Station, Jiangdu County, Yangzhou, Jiangsu Province, China. Water is delivered to Xuzhou via 10 stages of lift pumping stations and regulation and storage in Hongze Lake and Luoma Lake. The route is more than $400 \mathrm{~km}$ in total, with a water diversion flow up to $470 \mathrm{~m}^{3} / \mathrm{s}$. This project can irrigate farmland of $2,799,000 \mathrm{hm}^{2}$ and is a major part of the eastern route of south-to-north water diversion project. 


\subsubsection{Dongjiang-Shenzhen water supply project}

This project transfers water from Dongjiang River (a branch of Zhujiang River) and delivers water to Shenzhen Reservoir via nine stages of lift pumping stations and then to Hong Kong through pipelines. Since its construction that began in 1964, the project has been expanded two times. Now it supplies 620 million $\mathrm{m}^{3}$ for Hong Kong each year, which accounts for $60 \%$ of total water amount used in Hong Kong and 1500 million $\mathrm{m}^{3}$ for Shenzhen each year.

\subsubsection{Luanhe-Tianjin water diversion project}

This project is an inter-basin water diversion project, which supplies water from the basin of the Luanhe River to Tianjin and Tangshan in the basin of the Haihe River. It started in 1982 and ended in 1986, with an annual water diversion amount up to 1.95 billion $\mathrm{m}^{3}$.

\subsubsection{Shandong Yellow River to Qingdao Project}

This project transfers water from Dayuzhang Diversion Sluice in the lower reaches of the Yellow River (with a design water diversion flow of $75 \mathrm{~m}^{3} / \mathrm{s}$ ) and delivers water Qingdao gradually via three stages of lift pumping stations (with a total head of $29.15 \mathrm{~m}$ ). The route is totally $262 \mathrm{~km}$ long, among which the canal is $213 \mathrm{~km}$ long and the pipeline $22 \mathrm{~km}$. The annual water diversion amount is 635 million $\mathrm{m}^{3}$.

\subsubsection{Datong River to Qinwangchuan Basin Project}

This project is a large-scale gravity irrigation project which transfers the water in the Datong River to the Qinwangchuan Basin $60 \mathrm{~km}$ from the north of Lanzhou. The design water diversion flow is $32 \mathrm{~m}^{3} / \mathrm{s}$, and the increased water diversion flow is $36 \mathrm{~m}^{3} / \mathrm{s}$. The project can irrigate an area of $860,000 \mathrm{mu}$ and transfer water of 443 million $\mathrm{m}^{3}$ each year after completion. Among the aqueduct, the tunnel is $74.9 \mathrm{~km}$ long, and the longest tunnel, Pandaoling tunnel, is $15.7 \mathrm{~km}$ long. It is the longest tunnel which has been completed in China up to now.

\subsubsection{South-to-north water diversion project}

This project is one of China's strategic projects, with eastern, middle, and western routes planned, involving 438 million people in the planned areas and with a water transfer scale of 44.8 billion $\mathrm{m}^{3}$. The project is built to solve water shortage in the regions of Northern China, especially in Huang-Huai-Hai River Basin. An entire layout with three main vertical routes and four main horizontal routes is formed by connecting three water transfer routes to the Yangtze River, the Yellow River, the Huaihe River, and the Haihe River. The purpose is to facilitate the realization of the reasonable allocation pattern for south-to-north water diversion and eastwest mutual aid in China. The middle and eastern routes of south-to-north water diversion project (Phase I) has been completed and started transferring water to Northern China. Up to now, the Western Route is being planned, but the construction has not started yet.

\subsection{Middle route of the south-to-north water diversion project (MRP)}

Among the south-to-north water diversion project, MRP plays the most strategic role. It will be introduced in the following three aspects: 


\subsubsection{Project overview and characteristics}

China has carried out the MRP with important strategic significance in order to alleviate the shortage of water resources in Henan, Hebei, Beijing, and Tianjin, optimize the allocation of water resources, improve the ecological environment, and promote sustainable development of society and economy. The MRP passed through more than 60 years from the proposal (on October 30, 1952) to exploration, survey, planning, design, and construction. It is put into formal operation on December 12, 2014.

The MRP (Figure 1) transfers water from Danjiangkou Reservoir, passing through Hubei, Henan, and Hebei and crossing the Yangtze River, the Huaihe River, the Yellow River, and the Haihe River. Water is transferred in an open channel by means of gravity flow to the Tuancheng Lake in Beijing and the Waihuan River in Tianjin. The MRP is characterized by (1) a long route: the general main canal is totally $1432 \mathrm{~km}, 1277 \mathrm{~km}$ of which is the length of the main canal, and $155 \mathrm{~km}$, the length of the Beijing to Tianjin Branch; (2) a large water transfer scale: the Phase I Project of MRP is designed with an annual water diversion amount of 9.5 billion $\mathrm{m}^{3}$, and the design discharge of Danjiangkou Reservoir into the canal head (i.e., Taocha Gate) is $350 \mathrm{~m}^{3} / \mathrm{s}$; (3) many buildings: the project has various kinds of buildings (totally more than 1800). Among them, the hydraulic control buildings include 63 check gates, 1 pumping station, 97 diversion gates, and 54 drainage gates; (4) strict control condition: the operation mode is constant downstream depth without a ready-to-use equalizing reservoir and with a low water head; the canals allow a small range of change in water stage, and the fluctuation of the water stage should not exceed $0.15 \mathrm{~m} / \mathrm{h}$ or $0.3 \mathrm{~m} / \mathrm{d}$ under normal operating conditions; (5) high water quality requirement: the supplied water should meet the Class II standard of China's Environmental Quality Standards for Surface Water (GB3838-2002); and (6) complicated operating conditions: the water division plans along the route tend to

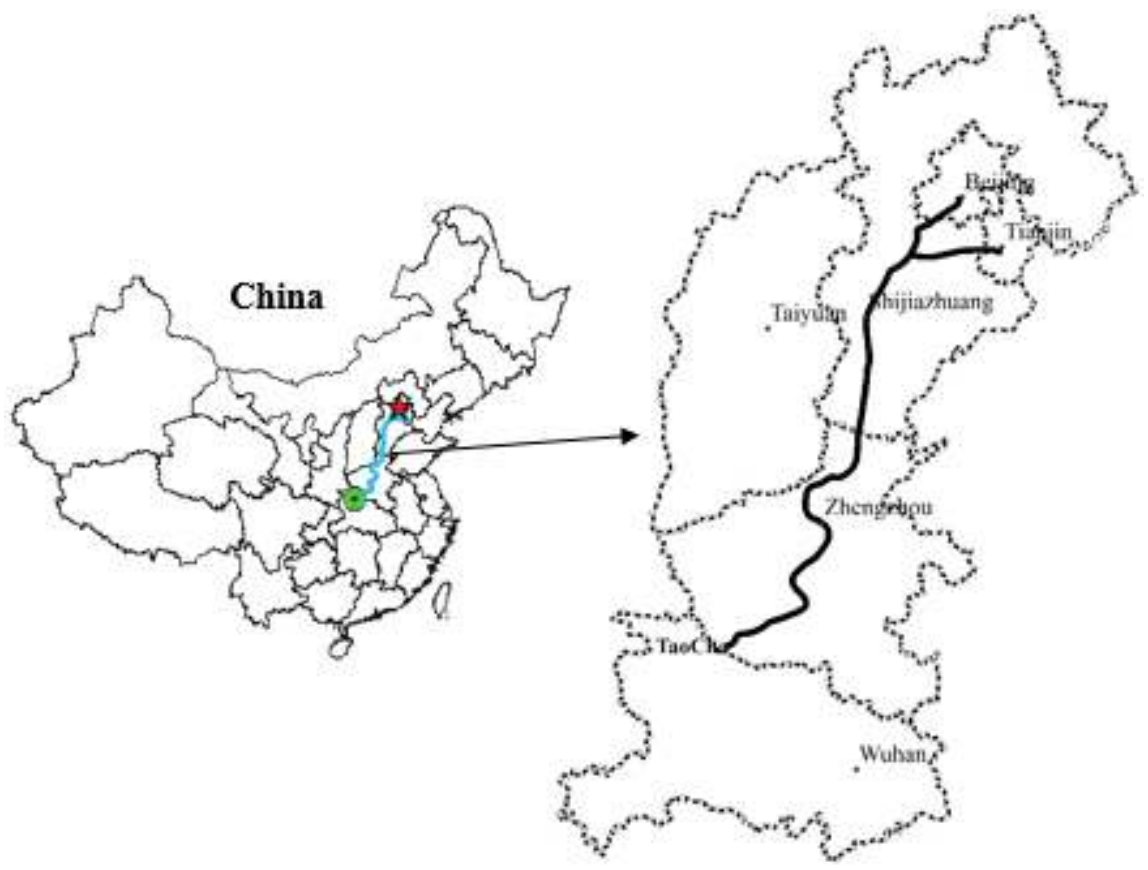

Figure 1.

Water diversion route of $M R P$. 
change frequently. In winter, water has to be transferred in an icy period with more risks. These characteristics make it difficult to operate and control the main canal of the MRP.

\subsubsection{Monitoring station network}

In order to support the operation and scheduling of the MRP, the Construction and Administration Bureau of the MRP (hereinafter called "CABMRP") has arranged a lot of monitoring stations along the route, including water amount and quality, engineering safety, video camera, etc. The water amount monitoring station network is made up by monitoring devices (flowmeter, water gauge, etc.) at more than 300 gate stations. The measured data for this research include the upstream and downstream water levels, opening and discharge of all check gates, and the discharge and water supply amount of diversion gates and drainage gates (some of the drainage gates are used as diversion gates sometimes). The water quality monitoring station network is comprised of 28 fixed monitoring stations, 13 automatic monitoring stations, 2 movable laboratories, etc. However, the measured water quality data have not been obtained due to various kinds of reasons.

\subsubsection{Risk of sudden water pollution accidents}

The MRP passes through large regions, involving totally 2218 enterprises producing dangerous chemicals, 1238 cross canal bridges, and many rivers and roads. These may cause sudden water pollution accidents, which endanger water quality safety, for example, a vehicle loaded with toxic materials falls into the canal due to traffic accidents; someone commits malicious poisoning; or the pollutants on the earth surface are brought by rainstorm or flood into the canal.

\section{Sudden water pollution accidents}

A sudden water pollution accident refers to a sudden event due to artificial or natural factors, etc., which brings plenty of pollutants into a water body. It can result in deteriorated water quality, affected living and production water and huge economic loss, endangering ecological environment and lead to a bad impact on the society [9].

Over the past few decades, a large number of sudden water pollution accidents have occurred worldwide. Major cases are Chemical Pollution Accident in the Rhine in 1986 [10], Benzene Pollution Accident in the Songhua River of China in 2005 [11], Oil Spill Accident in the Gulf of Mexico in 2010 [12], Nuclear Accident in Fukushima, Japan [13], etc. The basic situation and hazards of the four above accidents are simply indicated in Figure 2 and Table 1.

The challenges of real world spills and accidents are as follows: First, the spread of pollutants is too fast and complicated to be monitored accurately. Second, the emergency measures are difficult to determine quickly and reasonably. Third, how to deal with the accidents mainly depends on human experience.

Long distance water diversion projects provide an important guarantee for the development of social economy, human living, ecological environment health, and so on. Under the background of frequent occurrence of all kinds of sudden water pollution accidents occur frequently, that long distance water diversion projects suffer from water pollution accident risks has become a water supply safety factor that cannot be ignored. Once a sudden water pollution accident occurs, great harm and bad social influence will be brought. 


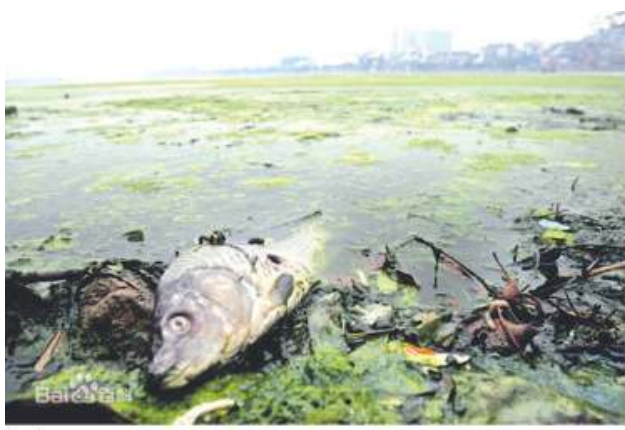

(a)

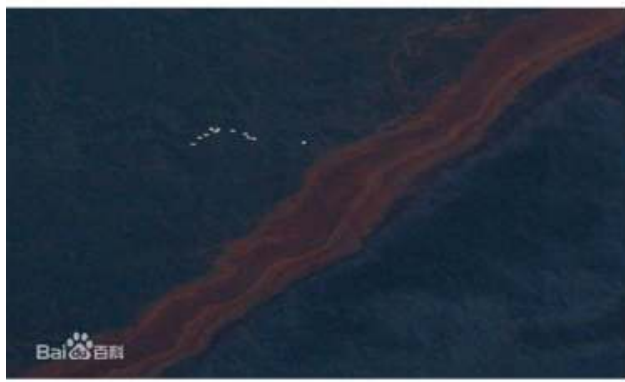

(c)

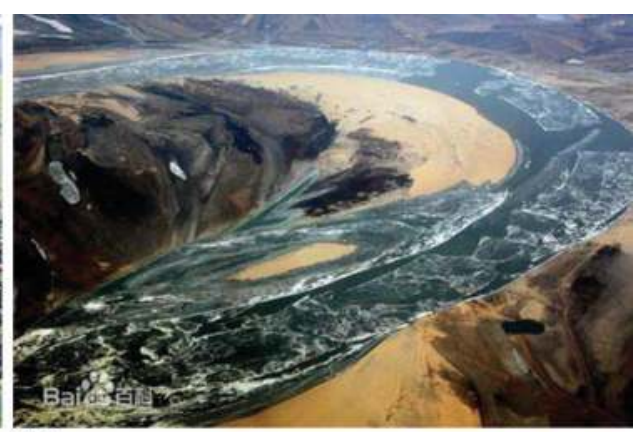

(b)
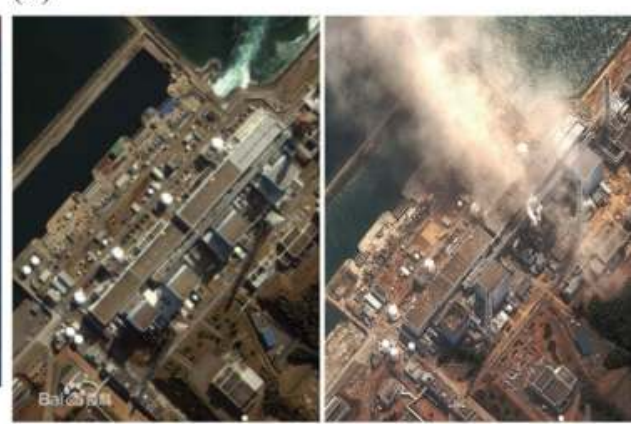

(d)

Figure 2.

Sudden water pollution accidents. (a) Chemical pollution accident in the Rhine; (b) benzene pollution accident in the Songhua River of China; (c) oil spill accident in the Gulf of Mexico; (d) nuclear accident in Fukushima, Japan.

\begin{tabular}{lll}
\hline Time & $\begin{array}{l}\text { Sudden water } \\
\text { pollution accidents }\end{array}$ & Overview and hazards of the accidents \\
\hline $\begin{array}{l}\text { November } \\
1986\end{array}$ & $\begin{array}{l}\text { Chemical pollution } \\
\text { accident in the Rhine }\end{array}$ & $\begin{array}{l}\text { The warehouse of Schweizerhalle Corporation near Basel, } \\
\text { Switzerland, caught a fire, and nearly 10,000 } \mathrm{m}^{3} \text { of fire water } \\
\text { polluted by toxic materials flew into the Rhine, forming a reddish } \\
\text { pollution zone of } 70 \text { km long, killing tons of fish, and causing } \\
\text { closedown of all water works along the river. }\end{array}$ \\
\hline $\begin{array}{l}\text { November } \\
2005\end{array}$ & $\begin{array}{l}\text { Benzene pollution } \\
\text { accident in the } \\
\text { Songhua River of } \\
\text { China }\end{array}$ & $\begin{array}{l}\text { One of the workshops of the Double Benzene Plant of Jilin } \\
\text { Petrochemical Company exploded, and about 100 tons of benzene } \\
\text { homologs and derivatives flew into the Songhua River, resulting } \\
\text { in severe pollution of the water therein, and affecting the living of } \\
\text { millions of people along the bank of the river. }\end{array}$ \\
\hline $\begin{array}{l}\text { April 2010 } \\
\text { Oil spill accident in } \\
\text { the Gulf of Mexico }\end{array}$ & $\begin{array}{l}\text { A coastal oil drilling platform in Louisiana in the south of the } \\
\text { United States exploded, leading to spill of a large quantity of oil and } \\
\text { an economic and environmental tragedy. }\end{array}$ \\
\hline $\begin{array}{l}\text { March } \\
\text { Fuclear accident in }\end{array}$ & $\begin{array}{l}\text { An earthquake happened in Japan caused Fukushima Nuclear } \\
\text { Power Plant reactor failure, a large number of radioactive sewage } \\
\text { was discharged into the sea, and many nearby residents evacuated. }\end{array}$ \\
\hline
\end{tabular}

Table 1.

Information on sudden water pollution accidents.

\section{Response measures for sudden water pollution accidents}

Worldwide researchers have done a lot of research on the response measures for sudden water pollution accidents, mainly involving simulation, traceability, operation and management system, and so on, which will be summarized as follows: 


\subsection{Simulation of sudden water pollution accidents}

Grifoll et al. [14] performed simulation and risk evaluation of the sudden water pollution accident owning to oil at Port of Barcelona by applying a 3D model and then proposed control measures to prevent water quality deterioration. Galabov et al. [15] conducted simulation of oil spill pollution events that might happen at 20 locations in the Burgas Bay by using a simulation program (including a variety of wind speed and direction conditions) to assess the range of impact due to oil spill pollution. Saadatpour et al. [16] established a 2D water quality simulation model; by using this model, they carried out simulation of different degrees of pollution caused by toxic materials at the Ilam Reservoir, putting forward emergency measures. Tang et al. [17] built a 1D hydrodynamic water quality model to make analysis of the pollutant diffusion process after sudden water pollution in the Main Route Project of the MRP; set a scene with three water flow rates, four pollutants, and three pollution amounts; and recommended reasonable emergency measures. Fan et al. [18] simulated the diffusion process of pollution due to a fluorescein sodium point source in the basin of the Paraiba do Sul River under many scenes. Samuels et al. [19] performed simulation of the transfer process of pollutants in rivers.

\subsection{Traceability of sudden water pollution accidents}

Fulvio et al. [20] combined a one-dimensional water quality modeling river with a geostatistical method and inversely analyzed the pollutant amount on where the pollution source location was known. Zhu et al. [21] combined a water quality model and a Bayesian estimation method and obtained the location probability distribution of pollution source. Based on the mathematical theory, Wang and $\mathrm{Xu}$ [22] proved the uniqueness of the pollution source position, and then Wang and Qiu [23] gave the related identification method. Yang et al. [24] proposed a multi-point source identification model of sudden water pollution accidents in surface waters based on differential evolution and MetropolisHastings-Markov Chain Monte Carlo. Zhang and Xin [11] discussed pollution source identification for water pollution accidents in small straight rivers by using genetic algorithm.

\subsection{Emergency operations of sudden water pollution accidents}

Lian et al. [25] built a 2D hydrodynamic water quality model based on CE-QUAL-W2 at the Three Gorges Reservoir and put forward different scheduling rules for the Three Gorges Reservoir to inhibit the outbreak of algal blooms according to the simulation results. Long et al. [26] established a joint emergency scheduling model for canals where an accident occurred and upstream and downstream sections thereof based on the risk evaluation of sudden water pollution accidents in the MRP. Xu et al. [27] set up a rapid emergency scheduling model for canals where an accident occurred in the MRP and put forward the method to operate two check gates in such canals. Zheng et al. [28] developed a 3D hydrodynamic water quality model based on the EFDC model at the Danjiangkou Reservoir and according to the simulation result, came up with joint emergency regulation and control methods for Danjiangkou Dam and Taocha Dam. Cheng and Qian [29] established an evaluation model based on a fuzzy comprehensive evaluation method to evaluate whether the emergency measures for sudden water pollution accidents are feasible. The indexes of evaluation are completeness, operability, effectiveness, flexibility, rapidity, and reasonableness. 


\subsection{Emergency management system for sudden water pollution accidents}

Dobbins [30] developed a decision-making support system for controlling the pollution risks arising out of inland water navigation accidents. Nine countries including Germany, Austria, etc. have developed "an emergency early warning system for Danube emergency accidents" with complete dangerous material database and accurate pollutant effect simulation capacity. The system serves in the simulation of emergency response to and other work of sudden water pollution accidents that happen in the Danube [31]. Bildstein et al. [32] integrated a water quality model in software called "SeauS," which can provide technical support for the simulation and treatment of sudden water pollution accidents. Rui et al. [33] integrated a hydrodynamic water quality model into a sudden water pollution accident response system based on GIS, and they applied it to the simulation and early warning of sudden water pollution accidents (TP and $\mathrm{COD}_{\mathrm{Mn}}$ ) at Xiangjia Dam.

\subsection{Summary}

Based on the analysis of the above literatures, simulation, traceability, regulation, control, management system, and other technologies should be included with regard to response measures for possible sudden water pollution accidents in the MRP. Among them, the hydrodynamic and water quality simulation technology can be used for predicting the pollutant transportation process after a sudden water pollution accident and for analyzing the effect of emergency operations; the sudden water pollution accident traceability technology can identify the pollution source fast and accurately; the emergency operation technology can be used to determine suitable emergency operation measures of control structures; the emergency management system can support the integration and visualization of professional model groups and provide decision-making support for engineering management companies and personnel.

\section{About this book}

This book provides technical support for potential sudden water pollution accidents in the MRP, with the main purpose of developing a practical emergency management system, by developing a 1D hydrodynamic and water quality model, a sudden water pollution accident source identification model, and an emergency operation model and finally integrating these models into the emergency management system. The chapters herein are arranged as follows:

Chapter 1 Introduction - Emergency Operation Technologies for Sudden Water Pollution Accidents: This chapter presents a simple introduction of the current development situation of long-distance water diversion projects in the world, focusing on the basic overview of the MRP and the existing risks that might arise from sudden water pollution accidents. The main contents of the book, the key technologies including "simulation-traceability-operation-system" for coping with sudden water pollution, are introduced through analysis of major hazards of sudden water pollution accidents and the current research of the response measures.

Chapter 2 Simulation Technology for Hydrodynamic and Water Quality in the Main Canal: This chapter provides a simple introduction of hydrodynamic water quality simulation software generally used at present, focusing on a method to build a 1D hydrodynamic and water quality model for the main canal of the 
MRP. The chapter also proves the precision of the hydrodynamic and water quality model by using the measured data and comparing with MIKE11 model, respectively.

Chapter 3 Traceability Technology for Sudden Water Pollution Accidents in Rivers: This chapter simply introduces the basic principles of sudden water pollution traceability and the traceability methods used currently, focusing on the new source identification model in the canal, and provides the results of sudden water pollution traceability technology obtained from analysis of practical applications.

Chapter 4 Emergency Operations of Sudden Water Pollution Accidents: This chapter simply introduces the strategies and goals of emergency operation of sudden water pollution accidents in the MRP, focusing on the emergency control algorithm for the gates at accident pool, upstream and downstream pools of the canal, and analyzes some cases.

Chapter 5 Emergency Management System for Sudden Water Pollution Accidents: This chapter offers the introduction of the service objects, building targets, system frame, system functions, system interface design of and system safety and maintenance rules for sudden water pollution accidents emergency management.

\section{Conclusions}

This chapter presents the introduction of the current development situation of long-distance water diversion projects in the world, the basic overview of the MRP, and the existing risks that might arise from sudden water pollution accidents. The contents researched for coping with sudden water pollution are summarized through analysis of major hazards of sudden water pollution accidents and the research of the countermeasures therefor made by predecessors.

\section{Acknowledgments}

This book is jointly supported by Major Science and Technology Program for Water Pollution Control and Treatment (2017ZX07108-001), State Key Laboratory of Simulation and Regulation of Water Cycle in River Basin (2016CG05), National Key Technology R\&D Program (2017YFC0406004), and National Key Technology R\&D Program of the Ministry of Science and Technology (2015BAB07B03). 


\section{Author details}

Xiaohui Lei ${ }^{1}$, Hezhen Zheng ${ }^{2,3 *}$ and Lingzhong Kong ${ }^{2}$

1 China Institute of Water Resources and Hydropower Research, State Key Laboratory of Simulation and Regulation of Water Cycle in River Basin, Beijing, China

2 Zhejiang University, Hangzhou, China

3 Changjiang Survey, Planning, Design and Research Co., Ltd., Wuhan, China

*Address all correspondence to: zhenghezhen@cjwsjy.com.cn

\section{IntechOpen}

(C) 2018 The Author(s). Licensee IntechOpen. This chapter is distributed under the terms of the Creative Commons Attribution License (http://creativecommons.org/licenses/ by/3.0), which permits unrestricted use, distribution, and reproduction in any medium, provided the original work is properly cited. (cc) BY 


\section{References}

[1] Lei X, Liao W, Wang Y, Jiang Y, Wang H, Tian Y.

Development and application of a distributed hydrological model: EasyDHM. Journal of Hydrologic Engineering. 2014;19(1):44-59

[2] Sun J, Lei X, Yu T, et al. Hydrological impacts of climate change in the upper reaches of the Yangtze River Basin. Quaternary International. 2013;304:62-74

[3] Yizi S, Lu S, Ling S, et al. Decomposition methods for analyzing changes of industrial water use. Journal of Hydrology. 2016;543:808-817

[4] Vorosmarty CJ et al. Global threats to human water security and river biodiversity. Nature. 2010;467:555-561

[5] Quentin Grafton R, Pittock J, Davis R, et al. Global insights into water resources, climate change and governance. Nature Climate Change. 2013;3:315-321

[6] Qiao Q-S, Yang K-L. Modeling unsteady open-channel flow for controller design. Journal of Irrigation and Drainage Engineering. 2010;136(6):383-391

[7] Lund JR, Israel M. Water transfers in water resource system. Journal of Water Resources Planning and Management. 1995;121(2):193-204

[8] Framji KK. Past and likely future developments in irrigation, drainage, and flood control measures in developing countries. International Commission on Irrigation \& Drainage. 1994;33(2):1-58

[9] Rebelo A, Ferra I, Gonçalves I, et al. A risk assessment model for water resources: Releases of dangerous and hazardous substances. Journal of Environmental Management. 2014;140:51-59
[10] Morscheidt W, Cavadias S, Rousseau F, et al. Pollution of the Rhine River: An introduction to numerical modelling. Education for Chemical Engineers. 2013;8(4):e119-e123

[11] Zhang S, Xin X. Pollutant source identification model for water pollution incidents in small straight rivers based on genetic algorithm. Applied Water Science. 2017;7(4):1955-1963

[12] Moss JA, McCurry C, Tominack $\mathrm{S}$, et al. Ciliated protists from the nepheloid layer and water column of sites affected by the deepwater horizon oil spill in the Northeastern Gulf of Mexico. Deep-Sea Research Part I: Oceanographic Research Papers. 2015;106:85-96

[13] Bailly du Bois P, Laguionie P, Boust $D$, et al. Estimation of marine sourceterm following Fukushima Dai-ichi accident. Journal of Environmental Radioactivity. 2012;114:2-9

[14] Grifoll M, Jordà G, Espino M, et al. A management system for accidental water pollution risk in a harbour: The Barcelona case study. Journal of Marine Systems. 2011;88(1):60-73

[15] Galabov V, Kortcheva A, Marinski J. Simulation of tanker accidents in the Bay of Burgas, using hydrodynamic model. Proceedings of the International Multidisciplinary Scientific

GeoConferences. 2012;3:993

[16] Saadatpour M, Afshar A. Multi objective simulation-optimization approach in pollution spill response management model in reservoirs. Journal of Water Resources Planning and Management. 2013;27:1851-1865

[17] Tang C, Yi Y, Yang Z, et al. Water pollution risk simulation and prediction in the main canal of the south-to-north water transfer project. Journal of Hydrology. 2014;519:2111-2120 
[18] Fan FM, Fleischmann AS, Collischonn W, et al. Large-scale analytical water quality model coupled with GIS for simulation of point sourced pollutant discharges. Environmental Modelling \& Software. 2015;64:58-71

[19] Samuels WB, Bahadur R, Ziemniak $\mathrm{C}$, et al. Development and application of the incident command tool for drinking water protection. Water and Environment Journal. 2015;29(1):1-15

[20] Fulvio B, Roberto R, Luca R. Source identification in river pollution problems: A geostatistical approach. Water Resources Research. 2005;1(7):23-30

[21] Zhu S, Liu GH, Wang LZ, Mao GH, Cheng WP, Huang YF. A Bayesian approach for the identification of pollution source in water quality model coupled with hydrodynamics. Journal of Sichuan University (Engineering Science Edition). 2009;41(5):30-35

[22] Wang ZW, Xu DH. Uniqueness and numerical methods for point source pollution of watershed. Journal of Ningxia University (Natural Science Edition). 2006;27(2):124-129

[23] Wang ZW, Qiu SF. Stability and numerical simulation of pollution point source identification in a watershed. Journal of Hydrodynamics. 2008;23(4):364-371

[24] Yang H, Shao D, Liu B, et al. Multipoint source identification of sudden water pollution accidents in surface waters based on differential evolution and Metropolis-Hastings-Markov Chain Monte Carlo. Stochastic Environmental Research and Risk Assessment.

2016;30:507-522

[25] Lian J, Yao Y, Ma C, et al. Reservoir operation rules for controlling algal blooms in a tributary to the impoundment of Three Gorges Dam. Water. 2014;6:3200-3223

[26] Long Y, Xu G, Ma C. Emergency control system based on the analytical hierarchy process and coordinated development degree model for sudden water pollution accidents in the middle route of the south-to-north water transfer project in China. Environmental Science and Pollution Research. 2016;23(12):12332-12342

[27] Xu G, Long Y, Ma C. A real-time, rapid emergency control model for sudden water pollution accident in long distance water transfer project. Water Science \& Technology: Water Supply. 2017;1:73-83

[28] Zheng H, Lei X, Shang Y, et al. Sudden water pollution accidents and reservoir emergency operations: Impact analysis at Danjiangkou Reservoir. Environmental Technology. 2018;39(6):787-803

[29] Cheng CY, Qian X. Evaluation of emergency planning for water pollution accidents in reservoir based on fuzzy comprehensive assessment. Procedia Environmental Sciences. 2010;2:566-570

[30] Dobbins JP. Development of an Inland Marine Transportation Risk Management Decision Support System. Nashville, Tennessee, USA: Vanderbilt University; 2001

[31] Zografos KG, Vasilakis GM, Giannouli IM. Methodological framework for developing decision support systems (DSS) for hazardous materials emergency response operations. Journal of Hazardous Materials. 2000;71(1-3):503-521

[32] Bildstein O, Vançon JP. Development of a propagation model to determine the spread of accidental pollution in rivers. Journal of Clinical Microbiology. 2011;32(8):1976-1979

[33] Rui Y, Shen D, Khalid S, et al. GIS-based emergency response system for sudden water pollution accidents. Physics and Chemistry of the Earth. 2015;79-82:115-121 